\title{
Microclimate Modification of Tall Moist Grasslands of Natal by Spring Burning
}

\author{
M.J. SAVAGE AND K. VERMEULEN
}

\begin{abstract}
The purpose of this study was to investigate modifying microclimatic effects of spring burning in tall grassland, long-term burning trials at Ukulinga, Pietermaritzburg, South Africa. Soil temperature (at $50 \mathrm{~mm}$ ), soil heat, net radiation and surface reflection coefficient were monitored on various cloudless days before and after burning. Four days after burning there was no significant increase in soil temperature but soil heat and net radiation increases and surface reflection coefficient decreases (from $15 \%$ to nearly $3 \%$ at local noon) were evident. Between burning date and first day of measurements, a rainfall of less than $2 \mathrm{~mm}$ occurred causing greater evaporation at the burnt site (due to greater net radiation) and hence lower soil temperatures, compared to the control site. Burning also resulted in an increase in sensible plus latent plus photosynthetic heat densities (from a daily total density of $9.0 \mathrm{MJ} \mathrm{m} \mathrm{m}^{-2}$ before to $9.9 \mathrm{MJ} \mathrm{m}^{-2}$ after burning) with soil heat density increasing by $50 \%$. Four weeks after, soil temperature and soil heat were greater for the burnt site compared to the control, but net radiation and surface reflection coefficient were not significantly different between the two sites. The appearance of green material some short time after burning is therefore probably a result of more favourable soil-plant water and surface energy relations.
\end{abstract}

Fire has been a natural phenomenon in the development of the tall grassland of Natal (Scott 1971). Today it is a widely used agricultural tool where grazing is seldom sufficient to ensure a uniform removal of top growth (Tainton 1978). Burning benefits plant growth primarily because of changes in the physical rather than chemical environment (Brown 1967, Fisher 1978).

Daubenmire (1968), in the brief section on microclimate in his review of the ecology of fire in grasslands, concluded: ".... with the exception of the limited (soil) temperature data that have been summarized, they (microclimate measurements) are almost nonexistent." Since then, Old (1969) has investigated some aspects. Effects of fire on the grassland microclimate are reviewed by Savage (1980b) and Cass et al. (1983).

Burning alters the grassland microclimate, and this paper reports on an investigation of some of these alterations, particularly with regard to surface reflection coefficient, soil heat flux density, soil temperature at $50 \mathrm{~mm}$, and surface net radiant flux density. Although reflection coefficients for many surfaces have been reported, few measurements are available for natural grasslands (Ripley and Redmann 1976) and even fewer for burnt grasslands. The reflection coefficient of a stand is an important microclimatological characteristic relevant to its energy balance (Ross 1975).

The authors are agrometeorologist and research assistant, Department of Soil Science and Agrometeorology, University of Natal, P.O. Box 375, Pietermaritzburg, Nata, South Africa, 3200.

The authors thank Professor N.M. Tainton (Dept. of Grassland Science, University of Natal) and Mr. B.J. Huntley (Council for Scientific and Industrial Research, Pretoria) for initiating this study; Dr. A.W. Bailey (University of Alberta, Dept. of Plant Science, Canada), Mr. M.T. Mentis (Dept. of Grassland Science, University of Natal) and the late Dr. P.J. Edwards (Pastures Section, Agriculture and Fisheries, Cedara) for their critical comments on the manuscript; Mr. P.N. Dovey and W. Geduld for their assistance in the field and laboratory.

Manuscript received January 6, 1981.
For convenience of the reader, terminology used in this paper will be defined (see Savage 1979, 1980b):

incident short wave radiation: solar energy incident per unit time (flux) per unit area (density) of surface $\left(\mathrm{J} \mathrm{s}^{-1} \mathrm{~m}^{-2}\right.$ or W $\mathrm{m}^{-2}$ );

surface reflection coefficient, $\mathrm{r}$ : percentage of incident short wave radiation reflected by a surface (\%);

soil heat or soil heat flux density, $\mathrm{F}_{\mathrm{z}}$ : energy per unit time per unit area entering the soil surface but measured at a very small distance away from the soil surface $\left(\mathrm{W} \mathrm{m}^{-2}\right)$;

latent heat/latent heat flux density, $\mathrm{F}_{\mathrm{w}}$ : energy per unit time per unit area expended in evaporating (energy loss by the surface) or condensing (energy gain by the surface) water, without a change in temperature $\left(\mathrm{W} \mathrm{m}^{-2}\right)$;

photosynthetic heat/heat flux density, $\mathrm{F}_{\mathrm{p}}$ : energy per unit time per unit area expended in assimilating carbon dioxide (including crop heat storage) $\left(\mathrm{W} \mathrm{m}^{-2}\right)$;

sensible heat/heat flux density, $F_{\mathrm{h}}$ : energy per unit time per unit area expended in heating or cooling the atmosphere $\left(\mathrm{W} \mathrm{m} \mathrm{m}^{-2}\right)$;

net radiation/net radiant flux density, $\mathrm{I}_{\mathrm{net}}$ : net radiant energy flux per unit surface area, or, more conveniently, $I_{n e t}=F_{w}$ $+F_{h}+F_{s}+F_{p}$ (all terms in $W^{-2}$ ).

\section{Study Area}

Long-term burning trials are being conducted at Ukulinga (Tainton and Mentis 1983), the University of Natal research farm, about $5 \mathrm{~km}$ southeast of Pietermaritzburg, Natal, South Af rica. The 30-year mean annual rainfall at Ukulinga is $733 \mathrm{~mm}$ with a standard deviation of $\pm 126 \mathrm{~mm}$. Average annual air temperature is $17.8^{\circ} \mathrm{C}$ and mean annual Class A-pan evaporation is $1422 \mathrm{~mm}$ (Savage 1981).

All measurements were performed at 2 virtually level sites (areas of $12.7 \mathrm{~m}$ by $18.3 \mathrm{~m}$ ). The "control" site has had biennial burns for the last 23 years with the last burn being a spring burn in 1979. The burnt site treatment was an annual spring burn with the 1980 burn occurring on 11 September.

\section{Materials and Methods}

Soil heat flux density $F_{s}$ (with SI unit $\mathrm{W} \mathrm{m}^{-2}$ ) was measured at the 2 positions at both sites using factory calibrated Middleton' soil heat flux plates. The plates were as close to the surface as possible causing no vegetation damage and very little soil disturbance. All plates had the same orientation. Lead wires emerging from the soil were staked to the ground to prevent plate disturbance and plates were buried 2 months before the first day of measurement.

Net radiation $I_{\text {net }}\left(W^{-2}\right)$ was measured using a factory calibrated Middleton $\mathrm{CN} 1$ net radiometer. Calibration errors were reduced by using the same radiometer over both sites. The radiometer has a pair of plastic domes covering the temperature sensing area sensing

The mention of proprietary products is for the convenience of the reader and does not imply endorsement or otherwise by the authors, the University of Natal, or the Council for Scientific and Industrial Research, Pretoria. 


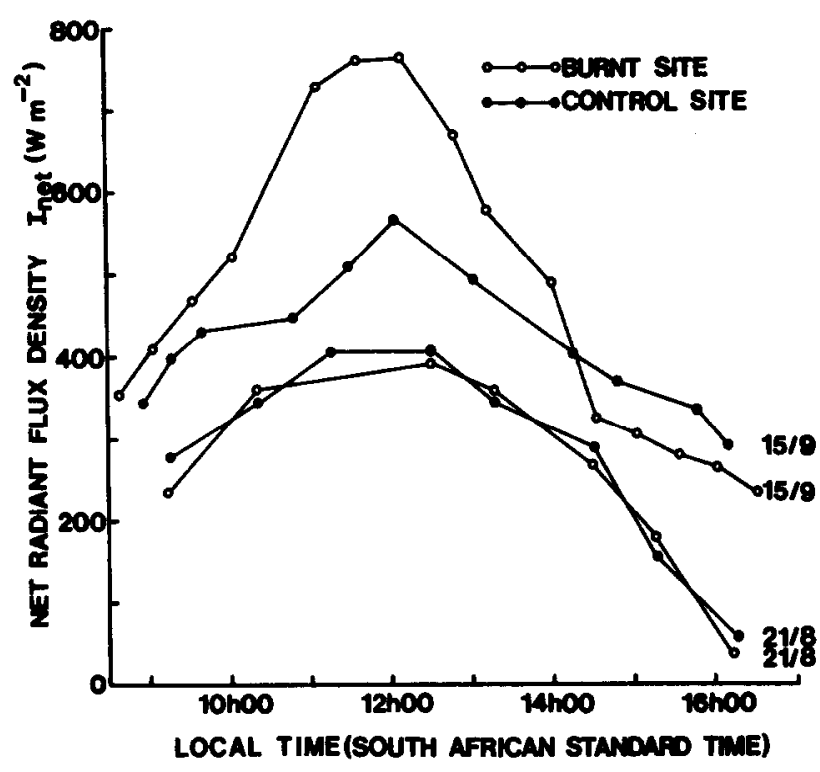

Fig. 1. Net radiant flux density $I_{\text {net }}\left(W \mathrm{~m}^{-2}\right)$ as a function of local time for both sites 3 weeks before burning $(21 / 8 / 80)$ and 4 days $(15 / 9 / 80)$ after burning.

both short and long wavelength radiation.

Incoming and reflected radiation were measured using a Kipp and Zonen solarimeter with a Moll thermopile. The instrument was heat shielded and calibrated against a Linke-Feussner actinometer (factory calibrated and traceable to a national standard). The solarimeter has a $150 \mathrm{~mm}$ diameter radiation shield to prevent underside sensor heating which reduces the voltage output corresponding to the incident short wave radiation. Most commercially available line pyranometers (tube solarimeters) are inadequate for the present purpose for this reason, but such a shield may easily be constructed. The glass dome of the solarimeter ensures measurement of short wave radiation (between 300 and $3000 \mathrm{~nm}$ ).

Voltage output from the three sensor types was mea sured using a

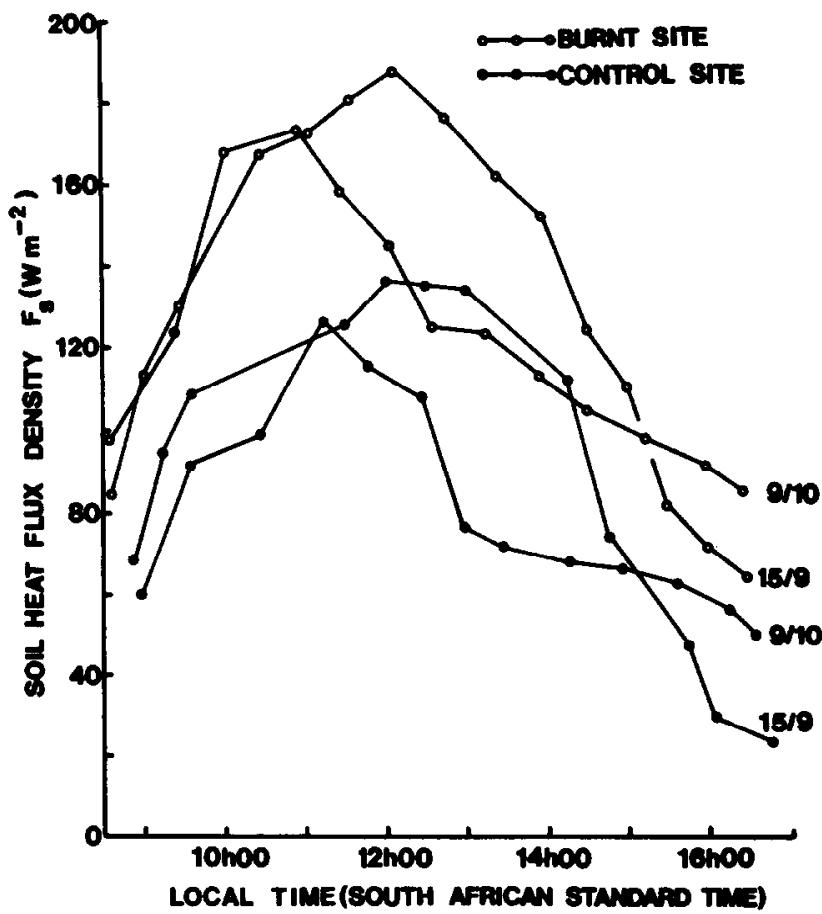

Fis. 2. Soil heat flux density $F_{\mathrm{s}}\left(W \mathrm{~m}^{-2}\right)$ as a function of local time for both sites 4 days (15/9) and 4 weeks $(9 / 10)$ after burning.

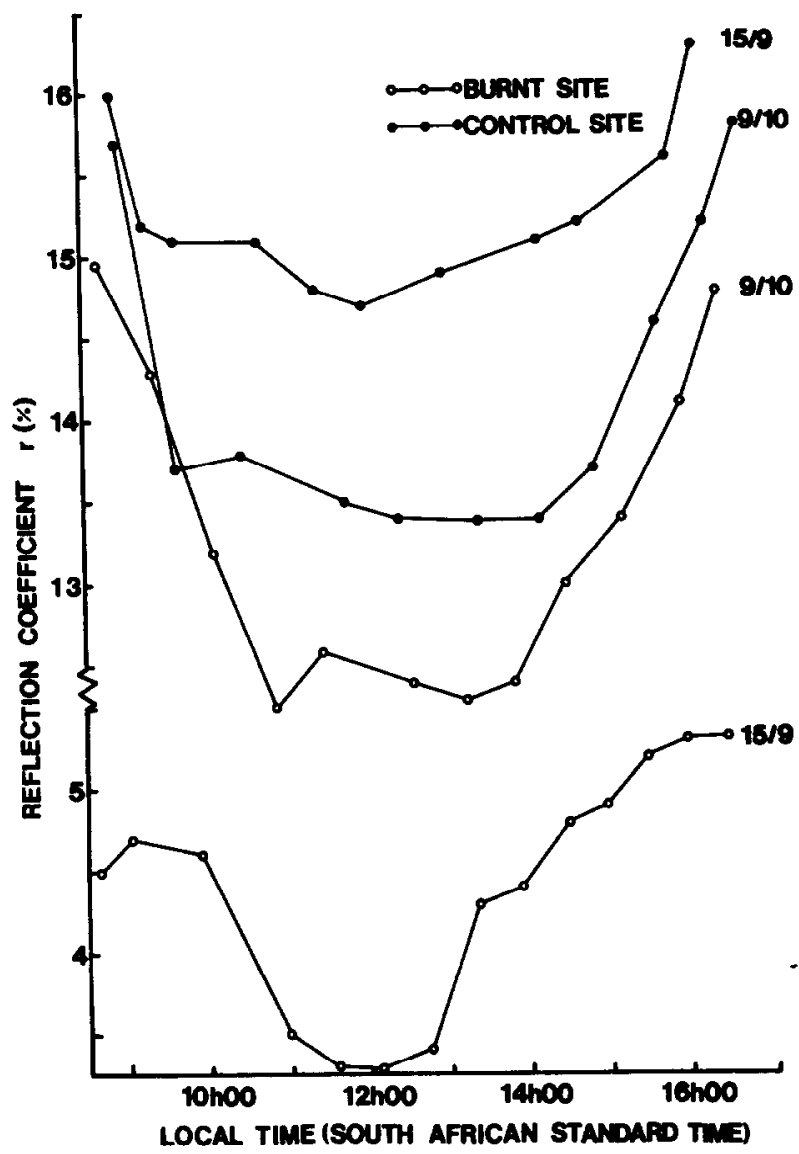

Fig. 3. Diurnal variation of surface reflection coefficient $r(\%)$ for both sites 4 days $(15 / 9)$ and 4 weeks $(9 / 10)$ after burning.

portable multimeter, at roughly each hour of the day (for both sites) on four cloudless days, two of the days being before burning and two after.

Soil and air temperatures were measured at both sites using three-wire PT-100 resistance thermometers (Savage 1980a). Soil thermometers were placed horizontally in undisturbed soil (about a horizontal distance of $1 \mathrm{~m}$ from the soil heat flux plates) at a depth of $50 \mathrm{~mm}$, two months prior to measurement. Temperature was read directly in ${ }^{\circ} \mathrm{C}$ using a Fluke RTD portable thermometer unit.

\section{Results and Discussion}

Figures 1, 2, and 3 show net radiation $I_{\text {net }}$, soil heat flux density $F_{s}$ and surface reflection coefficient $r$ for 2 dates before burning and 2 dates after for both burnt and control sites. Burning was on 11 September 1980 with less than $2 \mathrm{~mm}$ of rainfall (on 12 September 1980) between burning date and first measurement day following burning (15 September 1980). Four days after burning, the burned surface local noon (South African Standard Time) reflectivity was $3.2 \%$ compared to $14.2 \%$ before burning (on 21 August) and $14.7 \%$ on the control site. Surface reflectivity of the burnt site may have been less than $3.2 \%$ immediately after burning were it not for the $2 \mathrm{~mm}$ rainfall. This reflectivity value is probably the lowest ever reported for a vegetated surface, although use of artificial mulches can result in values less than $5 \%$ (Kalma and Fuchs 1976).

Reporting on work by Harrison (1978), Gandar (1979) quotes a surface reflectivity midday value of $7 \%$ following burning at Nylsvley Nature Reserve (near Pretoria). This value was half that of the control site but a total of $23 \mathrm{~mm}$ rainfall occurred between date of burn and first surface reflectivity measurements (more than a ten day interval).

Reduction in midday surface reflection coefficient $(r)$ value due to burning, resulted in the local noon net radiation $\left(I_{\text {net }}\right)$ value increase $\left(761 \mathrm{~W} \mathrm{~m}^{-2}\right.$ compared to $564 \mathrm{~W} \mathrm{~m}^{-2}$ for the control site 4 
Table 1. Values of the energy density terms $\left(\mathrm{MJ} \mathrm{m}^{-2}\right)$, also ex pressed as a percentage of the total incident short wave radiant density, for both sites for 15 September and 9 October 1980, 11 September being the date of the spring burn (calculated prior to rounding off process).

\begin{tabular}{|c|c|c|c|c|c|c|c|c|}
\hline \multirow[b]{3}{*}{ Energy term } & \multicolumn{4}{|c|}{ Burnt site } & \multicolumn{4}{|c|}{ Control site } \\
\hline & \multicolumn{2}{|c|}{$\begin{array}{c}\text { Energy density } \\
\left(\mathbf{M J ~ m}^{-2}\right)\end{array}$} & \multicolumn{2}{|c|}{$\begin{array}{c}\% \text { of short wave radiation } \\
(\%)\end{array}$} & \multicolumn{2}{|c|}{$\begin{array}{l}\text { Energy density } \\
\quad \mathrm{MJ} \mathrm{m}^{-2} \text { ) }\end{array}$} & \multicolumn{2}{|c|}{$\begin{array}{c}\% \text { of short wave radiation } \\
(\%)\end{array}$} \\
\hline & $15 / 9$ & $9 / 10$ & $15 / 9$ & $9 / 10$ & $15 / 9$ & $9 / 10$ & $15 / 9$ & $9 / 10$ \\
\hline Incident short wave & 18.0 & 22.5 & - & - & 18.0 & 22.5 & - & - \\
\hline Amount reflected & 0.8 & 4.2 & 4 & 19 & 2.5 & 3.3 & 14 & 15 \\
\hline Net radiation & 13.9 & 14.1 & - & - & 11.7 & 15.0 & - & - \\
\hline Soil heat & 4.0 & 3.3 & 22 & 14 & 2.7 & 2.3 & 15 & 10 \\
\hline $\begin{array}{l}\text { Sensible heat plus latent plus } \\
\text { photosynthetic }\end{array}$ & 9.9 & 10.8 & 55 & 48 & 9.0 & 12.7 & 50 & 56 \\
\hline
\end{tabular}

days following burning). Some of this energy increase entered the soil, local noon soil heat flux density being $187 \mathrm{~W} \mathrm{~m}^{-2}$ compared to $136 \mathrm{~W} \mathrm{~m}$ on 15 September for burnt and control sites respectively. Ripley and Redmann (1976) found that local noon soil heat flux density $F_{s}$ did not exceed $120 \mathrm{~W} \mathrm{~m}^{-2}$ during mid summer at Matador, Sask., in Canada.

The various radiation flux density values were integrated (over the whole day) for 15 September and 9 October for both sites to

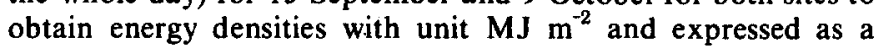
percentage of total short wave radiant density (Table 1). Comparing control and burnt sites following burning, there was a slight increase $\left(9.0\right.$ to $\left.9.9 \mathrm{MJ} \mathrm{m}^{-2}\right)$ in sensible plus latent plus photosynthetic heat energy densities (subsequently referred to as remainder term), with increases in net and soil heat densities. Between 15 September and 9 October for the burnt site, the remainder term decreased from $55 \%$ of incident short wave radiation to $48 \%$. Immediately after burning, it is probable that sensible heat $\left(F_{h}\right)$ would dominate in the remainder term but that its importance would decrease with time after burning. The mean daily surface reflection was $4.3 \%$ for the burnt site and $13.9 \%$ for the control site, 4 days after burning.

The mean soil temperature at $50 \mathrm{~mm}$ (averaged between $08 \mathrm{~h} 00$ $17 \mathrm{~h} 00$ ) was 17.9 and $18.3^{\circ} \mathrm{C}$ for burnt and cont rol sites respectively on 15 September and 24.8 (burnt) and $22.0^{\circ} \mathrm{C}$ (control) for 9 October. Soon after burning soil temperature at $50 \mathrm{~mm}$ appeared to decrease because of increased soil surface evaporation resulting from the $2 \mathrm{~mm}$ rainfall. It would appear that increases in soil temperature at this depth cannot play an immediately important role in vegetation change associated with burning, provided there is ample soil water, as emphasized by many studies(Mes 1958, Peet 1971, Raison 1979, Rice and Parenti 1978). The appearance of green material some short time after burning (Fisher 1978) is therefore as a result of more favourable soil-plant water (Fisher 1978, Redmann 1978) and surface energy relations. This study shows (Table 1) an immediate increase in soil heat energy density $\left(4.0\right.$ compared to $\left.2.7 \mathrm{MJ} \mathrm{m}^{-2}\right)$ and an overall increase $(9.9$ to $9.0 \mathrm{MJ}$ $\mathrm{m}^{-2}$ ) in the remainder term (sensible, latent and photosynthetic heat energy density), following burning.

Four weeks after burning ( 9 October), soil heat density for the burnt site was slightly grcater than that of the control but there was no significant difference between net radiation, the remainder term (Table 1) and surface reflection coefficient (Fig. 3) for the 2 sites. Greater amount of soil heat for the burnt site was due to the lesser attenuation of radiation through the canopy, compared to the control site; this in turn caused greater soil temperatures for the burnt site.

Burning decreased the surface reflection coefficient which in turn increased net radiation, energy entering the soil and energy terms associated with sensible and latent heat and photosynthetic. It was probably these factors, in the presence of water, which caused rapid vegetation growth following burning and not soil temperature increases. Four days after burning, there was no measurable increase in soil temperature, at $50 \mathrm{~mm}$, due to burning, mainly because of rainfall of nearly $2 \mathrm{~mm}$ that occurred between date of burning and first post-burn measurements. Four weeks after burning, soil temperature and soil heat were greater for the burnt site due to observed vegetation height differences, but there was no significant difference in surface reflection coefficient and net radiation between the two sites.

\section{Literature Cited}

Brown, C.J. 1967. Growth and energy relationships on burned and unburned prairie in southern Wisconsin. M.S. thesis, Univ. Wisconsin, Madison.

Cass, A., M.J. Savage, and F.M. Wallis. 1983. The effect of fire on soil and microclimate. In: Booysen P. de V. and Tainton, N.M. (eds.). Ecological Effects of Fire in South Africa. (In press).

Daubenmire, R. 1968. Ecology of fire in grasslands. Adv. Ecol. Res. 5:209266.

Fisher, M.J. 1978. The rec overy of leaf water potential following burning of two droughted tropical pasture species. Aust. J. Exp. Agr. Anim. Hus. 18:423-425.

Gandar, M.V. 1979. Description of a fire and its effects in the Nylsvley Nature Reserve. Council for Scientific and Industrial Research (Pretoria, South Africa).

Harrison, T.D. 1978. Report on maximum temperature measurements during the Nylsvley veld fire of 6th September 1978 and on post fire micrometeorological measurements. Council for Scientific and Industrial Research (Pretoria, South Africa).

Kalma, J.D., and M. Fuchs. 1976. Citrus orchards. In: Monteith, J.L. (ed.) Vegetation and the Atmosphere, Volume 2. p. 309-328. Academic Press, Lond on.

Mes, M.G. 1958. The influence of veld burning or mowing on the water, nitrogen and ash content of grasses. S. Afr. J. Agric. Sci. 54:83-86.

Old, S.M. 1969. Microclimate, fire and plant production in an Illinois prairie. Ecol. Monog. 39:355-384.

Peet, M.M. 1971. The effect of burning on microclimate and production of Wisconsin tall-grass prairie. M.S. thesis, Univ. Wisconsin, Madison.

Raison, R.J. 1979. Modifications of the soil environment by vegetation fires, with particular reference to nitrogen transformations: a review. Plant Soil 51:73-108.

Redmann, R.E. 1978. Plant and soil water potentials following fire in a northem mixed grassland. J. Range Manage. 31:443-445.

Rice, E.L., and R.L. Parenti. 1978. Causes of decreases in productivity in undisturbed tall grass prairie. Amer. J. Bot. 65:1091-1097.

Ripley, E.A., and R.E. Redmann. 1976. Grassland p. 349-398. In: Monteith, J.L. (ed.). Vegetation and the Atmosphere, Volume 2. Academic Press, London.

Ross, J. 1975. Radiative transfer in plant communities. p. 13-55. In: Monteith, J.L. (ed.) Vegetation and the Atmosphere, Volume 1. Academic Press, London.

Savage, M.J. 1979. Use of the international system of units in the plant sciences. HortScience 14:492-495.

Savage, M.J. 1980a. An inexpensive resistance thermometer for air temperature, soil and relative humidity measurements. Agrochemophysica 12:1-3.

Savage, M.J. 1980b. Fire and the grassland microclimate. Herb. Abstr. 50:589-603.

Savage, M.J. 1981. Climate of Ukulinga. Unpubl. Univ. of Natal report. 15 p.

Scott, J.D. 1971. Veld burning in Natal. Proc. Tall Timbers Fire Ecol. Conf. 11:33-51.

Tainton, N.M. 1978. Fire in the management of humid grasslands in South Africa. Proc. Internat. Range Cong. 1:684-686.

Tainton, N.M., and M.T. Mentis. 1983. Fire in grassland. In: Booysen, P. de V. and Tainton, N.M. (eds). Ecological Effects of Fire in South Africa. (In press). 